\title{
Prevalence of bovine tuberculosis in the Aksu Region of Xinjiang, China, between 1985 and 2016
}

[Prevalência de tuberculose bovina na região Aksu de Xinjiang, China, entre 1985 e 2016]

\author{
Y.H. $\operatorname{Liu}^{1 \#}$, Q. Kang ${ }^{2 \#}$, B. Yang ${ }^{3 \#}$, F. $L^{1,2}{ }^{1,2}$ X.Q. $L i^{1}$, L. Zhang ${ }^{1}$, L. Zhao ${ }^{1 *}$ \\ ${ }^{1}$ College of Animal Science - Tarim University - Alar, Xinjiang, China \\ ${ }^{2}$ Animal Loimia Controlling and Diagnostic Center of Aksu Region - Aksu, Xinjiang, China \\ ${ }^{3}$ Animal Disease Control Center of Ordos - Ordos, China
}

\author{
Y.H. Liu1\# \\ https://orcid.org/0000-0003-4432-9433 \\ Q. Kang2\# \\ https://orcid.org/0000-0001-5926-3946 \\ B. Yang3\# \\ https://orcid.org/0000-0002-8701-1727 \\ F. Li1, 2 \\ https://orcid.org/0000-0003-0689-8811 \\ X.Q. Li1 \\ https://orcid.org/0000-0002-7296-7179 \\ L. Zhang1 \\ https://orcid.org/ 0000-0001-9739-0663 \\ L. Zhao1* \\ https://orcid.org/0000-0001-8538-5605
}

Prevalence of bovine tuberculosis infection in cattle in Aksu Prefecture determined by intradermal tuberculin skin test (TST), between 1985 and 2016. Cattle were analyzed according to region, feeding pattern, herds and age. A total of 890,009 cattle were tested, with overall bovine tuberculosis prevalence of $0.13 \%(1172 / 890009)$. Statistically significant difference was found in feeding pattern and herds. Prevalence in cows $(0.19 \%, 615 / 327022)$ was higher than that in beeves $(\mathrm{P}<0.01, \mathrm{OR}=1.903,95 \% \mathrm{CI}=$ 1.696 to 2.134). Significant difference $(\mathrm{P}<0.01 ; \mathrm{OR}=2.238,95 \% ; \mathrm{CI}=1.937$ to 2.585$)$ was evident for rates for bovine tuberculosis in the peasant household $(0.12 \%, 942 / 802343)$ and farm groups $(0.26 \%$, 230/87666). The overall prevalence of bTB was decreased in the Aksu Prefecture, especially the positive rate was under $0.1 \%$ in $2010 \mathrm{~s}$. We concluded that the control measures forbovine tuberculosis in the Aksu region cattle herds are effective.

Keywords: prevalence, bovine tuberculosis, aksu prefecture

\section{RESUMO}

Prevalência de infecção por tuberculose bovina em gado na prefeitura de Aksu determinada por teste cutâneo tuberculínico (TST) entre 1985 e 2016 foi avaliada. O gado foi analisado de acordo com região, padrão alimentar, rebanho e idade. Um total de 890009 animais foram testados, com prevalência de 0,13\% de tuberculose bovina (1172/890009). Diferença estatisticamente significativa foi encontrada em padrão alimentar e rebanhos. Prevalência em vacas $(0,19 \%, 615 / 327022)$ foi mais alta que em bois $(P<$ 0,01, $O R=1,903,95 \% C I=1,696$ a 2,134). Diferenças significativas $(P<0,01 ; O R=2,238,95 \%$; $C I=$ 1,937 a 2,585) foram evidentes em taxas para tuberculose bovina em casas de camponeses $(0,12 \%$, 942/802343) e grupos de fazendeiros (0,26\%, 230/87666). A prevalência de bTB caiu na prefeitura Aksu, a taxa positiva se encontrava abaixo de $0.1 \%$ a partir de 2010. Conclui-se que as medidas de controle para tuberculose bovina na região de Aksu foram eficazes.

Palavras-chave: prevalência, tuberculose bovina, aksu

\section{INTRODUCTION}

Infectious diseases are important factors affecting the health of populations. Bacterial zoonoses still represent a serious medical problem (Wang et al., 2012; Karabay et al., 2004). Bovine tuberculosis (bTB) is a chronic debilitating and contagious disease of livestock,

Recebido em 27 de janeiro de 2018

Aceito em 25 de setembro de 2018

\# Equal contributors

*Autor para correspondência (corresponding author)

E-mail: zhaolidky@ 126.com wildlife and humans, mainly due to Mycobacterium bovis (Humblet et al., 2009; Katale et al., 2013). Cattle may serve as the main host for M. bovis worldwide (Gumi et al., 2011), while many or most domestic animals such as pigs, dogs, cats, horses and sheep are considered to be spill-over hosts (Franck et al., 2005; Dejene et al., 2016). Aerosol is considered to be the primary transmission pathway of infection in animals (Gumi et al., 2011; Franck et al., 2005). 
Other transmission pathways of infection such as ingestion of contaminated feeds, water and fomites have been confirmed (Gumi et al., 2011).

While most cattle infected with $M$. bovis usually exhibit a chronic disease often characterized by lesions in the lungs and the lymph nodes of the head and thoracic cavity, progressive emaciation, diarrhea and reduced milk yields can also occur. Most cases of bovine tuberculosis infection are inapparent and lack clinical symptoms. The main pathologic changes of bovine tuberculosis are tuberculous nodules and caseous necrosis or calcified nodules in variety of tissues and organs.

Bovine tuberculosis is a serious disease with potential public health and economic costs to society, since it can significantly affect international trade of animals and their products and create productivity losses (Ayele et al., 2004; Dejene et al., 2016). Bovine tuberculosis, which is currently ranked as the 7th highest in the world (Gumi et al., 2012), is a significant public health and food safety concern and considered as a second-class animal epidemic disease in China.
Several surveys on bovine tuberculosis in cow were conducted in some provinces in China in recent years (Ma et al., 2012; Li et al., 2012; Xin and An, 2007; Gan, 2008; Fu et al., 2004). However, no studies have been reported on the prevalence of bovine tuberculosis in the Aksu region. The current study determined to estimate the risk factors associated with exposure to the pathogen of bovine tuberculosis infection in cow in this region.

\section{MATERIALS AND METHODS}

The Aksu Prefecture, which comprises 1 city (Aksu) and 8 counties (Xayar, Kuqa, Baicheng, Xinhe, Wensu, Uqturpan, Kalpin and Awat), is an important area in South Xinjiang. The district of study (Figure 1) is located at $78^{\circ} 03^{\prime}$ to $84^{\circ} 07^{\prime} \mathrm{N}$ and $39^{\circ} 30^{\prime}$ to $42^{\circ} 41^{\prime} \mathrm{E}$. The Aksu Prefecture has a total land area of $132,500 \mathrm{~km}^{2}$ and a human population of approximately 2.5 million. The annual rainfall in this region varies between 42.4 and $94.4 \mathrm{~mm}$. Currently, the livestock population consists of 354,200 head of cattle, 208,500 pigs, 4.11 million sheep and 1.35 million goats. Livestock husbandry is regarded as an important source of income in the Aksu Prefecture.

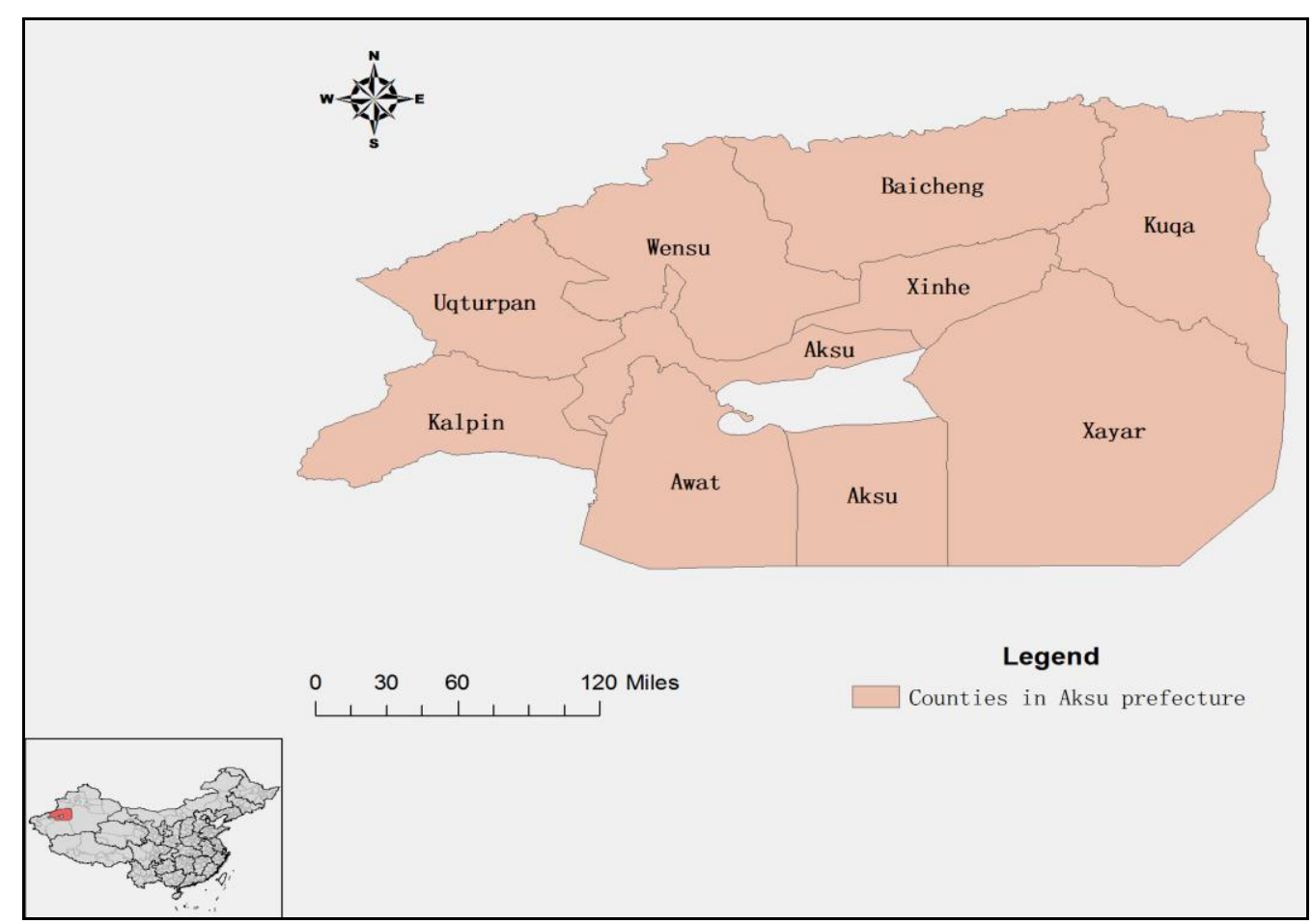

Figure 1. Aksu Prefecture administrative map. 
The current survey was implemented from 1985 to 2016, and 890,009 samples were collected from dairy herds and $10 \%$ beef cattle in the whole Aksu Prefecture (total approximate 6 million cattle, including cows and beef). All tasks were conducted by Animal Loimia Controlling and Diagnostic Center of Aksu Region. The experiment was performed with pure bovine tuberculin (PPD, produced by Harbin Pharmaceutical Group Bio-vaccine Co, Ltd.) skin allergy test (TST), according to the diagnostic techniques for tuberculosis of animal (GB/T18645-2002) methods. Biometric data from the cattle, including variety and feeding patterns were acquired from the animal owners or medical records.

The data were analyzed ( $\chi^{2}$-test) using the statistical software package SPSS version 20.0 (SPSS Inc., Chicago, IL, USA). The risk factors, including variety and feeding pattern were noted in present survey. Identification of a risk factor required a $95 \%$ confidence level $(\mathrm{P}<0.05)$ as well as a biologically plausible association between the factor and rate of allergic reaction to bovine tuberculosis.

\section{RESULTS}

The results of the TST detections on bovine tuberculosis positive samples are shown in Table 1. Among the 890,009 cattle, $1172(0.13 \%)$ were positive by TST. The prevalence in cows $(0.19 \%$, $615 / 327022)$ and in farm group $(0.26 \%$, 230/87666) were higher than that in beeves $(\mathrm{AFe}=0.300 ; \mathrm{OR}=1.903,95 \% ; \mathrm{CI}=1.696$ to 2.134) and in peasant household groups (AFe= $0.499 ; \mathrm{OR}=2.238,95 \% ; \mathrm{CI}=1.937$ to 2.585$)$ (Table 1).

Table 1. Prevalence of bovine tuberculosis infection in cattle in Aksu Prefecture determined by TST

\begin{tabular}{lcccc}
\multicolumn{1}{c}{ Variable } & Number of cattle $(\%)$ & Positive cattle $(\%)$ & \multicolumn{2}{c}{ single-factor analysis } \\
Total & $890009(100)$ & $1172(0.13)$ & & AFe/P \\
Variety & & & & \\
Cows & $327022(36.74)$ & $615(0.19)$ & 1 & \\
Beeves & $562987(63.26)$ & $557(0.10)$ & $1.903(1.696-2.134)$ & $0.300 /<0.01$ \\
Feeding pattern & & & & \\
Farm $(\geq 20)$ & $87666(9.85)$ & $230(0.26)$ & $2.238(1.937-2.585)$ & $0.499 /<0.01$ \\
Peasant household & $802343(90.15)$ & $942(0.12)$ & 2.06 \\
\hline
\end{tabular}

The prevalence of bovine tuberculosis infection from 1980 s to 2010 s was $0.04 \%(39 / 104462)$ in Aksu, $0.19 \%(156 / 82529)$ in Xayar, $0.21 \%$ $(304 / 145964)$ in Kuqa, $0.10 \%(88 / 88183)$ in Baicheng, $0.08 \%(41 / 49426)$ in Xinhe, $0.12 \%$ $(240 / 201567)$ in Wensu, $0.11 \%(72 / 68189)$ in Uqturpan, $0.10 \%(37 / 35883)$ in Kalpin and $0.17 \%(195 / 113806)$ in Awat (Table 2).
The prevalence of bovine tuberculosis infection in Aksu Prefecture was $0.18 \%(222 / 120847)$ in 1980 s, $0.12 \%$ in 1990 s $(208 / 175962), 0.19 \%$ in $2000 \mathrm{~s}(687 / 352938)$ and $0.02 \%$ in $2010 \mathrm{~s}$ (55/240262).

Table 2. Prevalence of bovine tuberculosis infection in cattle in different region in Aksu Prefecture determined by TST

\begin{tabular}{|c|c|c|c|c|c|c|c|c|c|c|}
\hline \multirow{2}{*}{$\begin{array}{l}\text { Area } \\
\text { Age }\end{array}$} & Aksu & Xayar & Kuqa & Baicheng & Xinhe & Wensu & Uqturpan & Kalpin & Awat & Total \\
\hline & \multicolumn{10}{|c|}{ Prevalence $(\%$, total tested $)$} \\
\hline \multirow{2}{*}{ 1980s } & 0.13 & 0.14 & 0.43 & 0.05 & 0.01 & 0.20 & 0.19 & 0.05 & 0.12 & 0.18 \\
\hline & (12279) & (11356) & $(21513)$ & (13975) & $(6993)$ & $(21120)$ & $(14575)$ & (1954) & (17082) & (120847) \\
\hline $1990 \mathrm{~s}$ & (18637) & $(21333)$ & $(24547)$ & $(17555)$ & (10218) & $(36415)$ & $(25108)$ & $(2151)$ & (19998) & $(175962)$ \\
\hline \multirow{2}{*}{$2000 s$} & 0.04 & 0.45 & 0.13 & 0.20 & 0.29 & 0.15 & 0.22 & 0.20 & 0.31 & 0.19 \\
\hline & (40884) & $(28368)$ & $(59836)$ & (26406) & $(12630)$ & (105405) & $(15817)$ & $(15106)$ & $(48486)$ & (352938) \\
\hline $2010 \mathrm{~s}$ & $(32662)$ & $(21472)$ & (40068) & (30247) & (19585) & (38627) & (12689) & (16672) & $(28240)$ & $(240262)$ \\
\hline \multirow{2}{*}{ Total } & 0.04 & 0.19 & 0.21 & 0.10 & 0.08 & 0.12 & 0.11 & 0.10 & 0.17 & 0.13 \\
\hline & (104462) & $(82529)$ & (145964) & (88183) & $(49426)$ & (201567) & (68189) & (35883) & (113806) & (890009) \\
\hline
\end{tabular}




\section{DISCUSSION}

The overall prevalence in cows in the Aksu Prefecture was $0.13 \% \quad(1172 / 890009)$, comparatively higher than those observed in Hui Autonomous Prefecture of Changji in Xinjiang (0.12\%) (Ma et al., 2012). However, the obtained prevalence in the Aksu Prefecture is lower than those in Hui Autonomous Prefecture of Changji at $0.27 \%$ from 2008 to 2011 , Urumqi city at $0.52 \%$ from 2007 to 2011 (Li et al., 2012) and Bole city at $3.82 \%$ from 2002 to 2004 (Xin and An, 2007) in Xinjiang, and Guangxi Zhuang Autonomous Region at $0.48 \%$ (Gan, 2008), as well as those in Qinghai province at $0.18 \%$ ( Fu et al., 2004).

The bovine tuberculosis in cattle was widespread in the 1940s, and outbreak in the 1950s, the highest infection rate of province reached $41.3 \%$ in China. In the 1970s, the epidemic of bovine tuberculosis achieved the historical high point, the infection rate of some area reached $67.4 \%$. In the $1980 \mathrm{~s}$, the positive rate of tuberculin skin allergy test achieved $2.68 \%$, and $28 \mathrm{P} / \mathrm{A} / \mathrm{M}$ (provinces, autonomous regions and municipalities) of China detected TB positive cattle, Xinjiang is particularly severe (Gan, 2008). In the study, the high prevalence of bTB was Kuqa in the 1980s and 1990s. In the 2000s, the prevalence of bTB in the Aksu Prefecture increased, except in Kuqa. The overall prevalence of bTB decreased in the Aksu Prefecture; the positive rate was under $0.1 \%$ in 2010s.

Tuberculin skin allergy test is the only recommended TB diagnosis method in the world organization for animal health (OIE). It has generally been used to determine the prevalence of bovine tuberculosis in China. The present study provides the first information on bovine tuberculosis infection in cattle in the Aksu Prefecture. In the current research, the prevalence in cows was $0.19 \%(615 / 327022)$, higher than that in beeves $(\mathrm{P}<0.01, \mathrm{OR}=1.903$, $95 \% \mathrm{CI}=1.696$ to 2.134$)$ at $0.10 \%(557 / 562987)$, possibly due to the susceptibility in difference between different breeds of cattle. Cows are more susceptible to TB.

Feeding pattern was another important risk factor for cow in the present survey. The prevalence of bovine tuberculosis infection was $0.26 \%$ and $0.12 \%$ in the farm and peasant household groups, respectively. Statistically significant differences between these values were obtained $(\mathrm{P}<0.01$; $\mathrm{OR}=2.238,95 \%$; $\mathrm{CI}=1.937$ to 2.585 ). Cattle in most of the farm are pastoralism, based on transhumance, which refers to a pattern of seasonal movement between dry season and wet season pastures. Given the feeding patterns and proximity to wildlife, studies are needed to explore the disease status, dynamics in the ecosystem and risk factors for bTB infection in animals and ultimately also humans.

The elimination of bTB from cattle is likely to be a difficult goal, but it is an extremely important one to accomplish. In Xinjiang, bTB has been controlled through "a test-and slaughter measures" for cattle and made major progress in decreasing the positive rate. Nevertheless, bTB remains a problem in some regions where surveillance and control activities are often inadequate or unavailable possibly due to lack of funds to support the whole exercise and compensate for tested and slaughtered animals (Katale et al., 2013). In conclusion, current control measures for bovine tuberculosis of Aksu Prefecture cattle herds might be valuated as effective.

\section{ACKNOWLEDGEMENT}

We thank the Animal Loimia Controlling and Diagnostic Center of Aksu Prefecture for supporting this work and permit to work under their jurisdiction. This study was funded by the National Natural Science Foundation of China (No. 31460655) and the open project of Key Laboratory of Tarim Animal Husbandry Science and Technology, Xinjiang Production \& Construction Corps (HS201501, HS201801).

\section{REFERENCES}

AYELE W.; NEILL S.; ZINSSTAG J. et al. Bovine tuberculosis: an old disease but a new threat to Africa. Int. J. Tuberc. Lung. Dis., v.8, p.924-937, 2004.

DEJENE S.; HEITKÖNIG I.; PRINS H. et al. Risk factors for bovine tuberculosis (bTB) in cattle in Ethiopia. PLOS ONE, v.11, p.1-16, 2016. 
FRANCK B.; MARIA L.; MARIE F. et al. Zoonotic aspects of Mycobacterium bovis and Mycobacterium avium-intracellulare complex (MAC). Vet. Res., v.36, p.411-436, 2005.

FU Y.; FU G.; WANG S. Investigation and prevention of cow tuberculosis in qinghai province. Chin. J. Vet. Med., v.40, p.31, 2004.

GAN H. Application and promotion of quarantine and detection to bovine tuberculosis in Guangxi. Guangxi Univ., 2008.

GUMI B.; SCHELLING E.; BERG S. et al. Zoonotic transmission of tuberculosis between pastoralists and Their Livestock in South-East Ethiopia. Ecohealth, v.9, p.139-149, 2012.

GUMI B.; SCHELLING E.; FIRDESSA R. et al. Prevalence of bovine tuberculosis in pastoral cattle herds in the Oromia region, southern Ethiopia. Trop. Anim. Health Prod., v.43, p.1081-1087, 2011.

HUMBLET, M.; BOSCHIROLI, M.; SAEGERMAN, C. Classification of worldwide bovine tuberculosis risk factors in cattle: a stratified approach. Vet. Res., v.40, p.50, 2009.

KARABAY O.; SERIN E.; TAMER A. et al. Hepatitis B carriage and Brucella seroprevalence in urban and rural areas of Bolu province of Turkey: a prospective epidemiologic study. Turk. J. Gastroenterol., v.15, p.11-13, 2004.
KATALE B.; MBUGI E.; KARIMURIBO, E. et al. Prevalence and risk factors for infection of bovine tuberculosis in indigenous cattle in the Serengeti ecosystem, Tanzania. BMC Vet. Res., v.9, p.823-834, 2013.

LI A.; ZHAO J.; HU D. et al. Epidemiological investigation and prevention of cow tuberculosis in Urumqi. Chin. J. Anim. Quarantine, v.29, p.52-54, 2012.

MA W.; LIU T.; MA J. Investigation and prevention measures of brucellosis and tuberculosis in Chang Ji. Xinjiang Anim. Husbandry, v.8, p.50-51, 2012.

WANG Y; BAI W.; GUO H. et al. Seroprevalence of brucellosis in sheep in the Aksu Region of Xinjiang Uygur Autonomous Region, People's Republic of China, between 1990 and 2010. Afr. J. Microbiol. Res., v.6, p.2512-2516, 2012.

XIN D.; AN N. Investigation of cow tuberculosis in bole of Xinjiang. Xinjiang Anim. Husbandry, v.1, p.38-39, 2007. 